\title{
The Kairos of karos: Revisiting notions of temporality in Africa ${ }^{1}$
}

\author{
Cilliers, Johan ${ }^{2}$ \\ Stellenbosch University \\ jcilliers@sun.ac.za
}

\begin{abstract}
Historically speaking, many Christian traditions have been influenced in their liturgy and preaching by Western understandings of time, i.e. as a linear progression from past, to present, to future. Africans do have a strong sense, not only of the past, but also of the future - in contrast to what some scholars would advocate. But African notions of time also harbour a particular understanding of the present, as the experience of social events. In Africa, time is not so much duration as it affects the fate of the individual, as it is the rhythm of the breathing of the social group. Perhaps the image of a spiral depicts best what Africans understand as time - a spiral that includes both linear and cyclical dimensions, as it reflects the rhythms of life. In this paper, an attempt is made to reflect on the contribution of a decolonised understanding of time on p reaching in Africa, in dialogue with keywords like memory, present, community, event, and movement.
\end{abstract}

\section{Africa: Timing the event}

"You (Western people) have watches; we (African people) have time." This piece of folklore, mostly spoken tongue-in-cheek, has often resulted in either mirth, or irritation. Does this, for instance, imply that Western people are (always) on time, i.e. always punctual (in line with German Punktlichkeit!), and that African people are always late, missing "deadlines", frustrating any attempt at timely "organising" an event? Or is it simply a way of saying that African people are not driven or mastered by any notion of "time"?

1 Paper delivered at the annual meeting of the Society for Practical Theology in South Africa, held in Stellenbosch, 18-20 January 2017, on the theme: Decolonizing Practical Theology in South Africa.

2 Professor in Homiletics and Liturgy at the Faculty of Theology, University of Stellenbosch, South Africa. 
Does the piece of folklore in fact articulate a more fundamental divide between Western and African understandings - and experiences - of time?

Few African scholars have contributed more to the discussion of "African Time" than John Mbiti, whose work has, on the one hand, been described as "the classic expression of African philosophy", but, on the other, has also become contested and at times even highly controversial. In his book, African Religions and Philosophy, published in 1969, Mbiti argues that Africans indeed have particular notions of time. According to Mbiti, African understanding of time is event-orientated rather than mathematically-calculated. ${ }^{4}$ Mbiti is of the opinion that "Time as separate [entity] does not "move"; only events come and go ..." His concern indeed seems not to be with "Western notions of abstract time which can be measured apart from events." 6

This event-orientated approach does have certain consequences for Mbiti's use of the (traditional) terms of "past, present, and future". According to him past events serve as markers for, and of time. Looking "backwards" from the present, decisive events in the history of a community is seen as events that shape, or at least situate the present moment. "Now" can only be understood in the light of "then". The past is described in terms of events: "In the time of the great drought of 1954 ...", "In the time of the floods of 1917 ..." etc. And, because the future does not (yet) contain events, the future cannot be understood as a long period - rather as short and foreseeable, stretching to six months and not beyond two years. ${ }^{7}$ It is rather the significant events of the past that define the present reality and tomorrow. In the words of Mbiti himself:

The linear concept of time in western thought, with an indefinite past, present and indefinite future is practically foreign to African

3 Kwasi Wiredu, "On Defining African Philosophy", in Tsenay Serequeberhan (ed.), African Philosophy: The Essential Readings (New York: Paragon House, 1991), p. 88.

4 John Mbiti, “The Concept of Time”, in African Religions and Philosophy (London: Heineman, 1969; second edition, 1990), pp. 15-28.

5 Newell S Booth, Jr. quoting Mbiti, “Time and African beliefs revisited”, Jacob K Olupona and Sulayman S Nyang (eds.), Religious Plurality in Africa, Essays in Honour of John S. Mbiti, Berlin and New York: Mouton De Gruyter, 1993, p. 84.

6 Booth, quoting Mbiti, “Time and African beliefs revisited”, p. 84.

7 Mbiti, Introduction to African Religion (London: Heinemann, 1971), p. 24. 
thinking. The future is virtually absent because events which lie in it have not taken place, they have not been realized and cannot, therefore constitute time... Actual time is therefore what is present and what is past. It moves "backward" rather than "forward"; and people set their minds not on future things, but chiefly on what has taken place. ${ }^{8}$

Contrasted to the notion of actual time, Mbiti speaks of potential time that which lies in the (near) future, and which falls “... in the category of inevitable or potential time ... The most significant consequence of this is that, according to traditional concepts, time is a two-dimensional phenomenon, with a long past, a present and virtually no future." What lies beyond the immediate (inevitable) future, could be described as "no time" (see diagram underneath)

Mbiti's understanding of African time relies heavily on the Kiikamba "tene period" or Kiswahili word, Zamani (originally Arabic) "as the centre of gravity in the Akamba conception of history: people's history and thinking and understanding of the world are oriented toward this finality ..." ${ }^{10} \mathrm{He}$ outlines his conception of the present using the notion of Sasa, (which could roughly be translated as "present"), but which is embedded in the "past" as Zamani. Events take place within the Sasa dimension, before moving "backwards" from Sasa into the Zamani. ${ }^{11}$ In a sense, Zamani is the beginning and end of everything. But, although being two dimensions of time, Zamani and Sasa are not separable. There is a reciprocal feeding into one another. Therefore, for instance, the ancestors are not absent in the present, but rather contemporary. ${ }^{12}$

Although it is not that easy, or even appropriate to define Mbiti's understanding of African time in exact terms, and although one runs the risk of again interpreting him according to Western (i.e. linear) constructs, I propose that we depict this understanding of time as follows:

8 Mbiti, African Religions and Philosophy, p. 17.

9 Mbiti, African Religions and Philosophy, p. 16.

10 Booth, quoting Mbiti, “Time and African beliefs revisited", p. 83.

11 Mbiti, African Religions and Philosophy, p. 23.

12 Mbiti, African Religions and Philosophy, p. 23. 


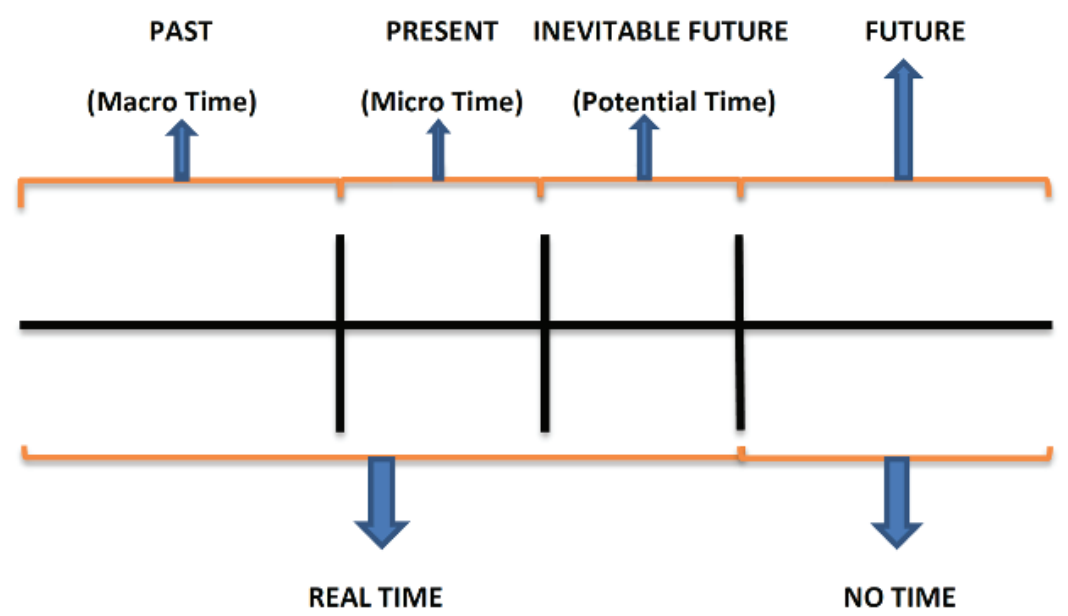

Sasa (the present) is in itself a complete time dimension - having its own short future, dynamic present and an experienced past. This is called micro time. Zamani is more than just "past" - it also has its own "past", "present", and "future". This could be called macro time. ${ }^{13}$ Zamani is the point beyond which nothing can go - it is the "graveyard" where all time and all events find their halting point, a type of final store house for time; the ocean of time in which everything is absorbed into reality. ${ }^{14}$ In effect, Zamani is used to describe "the stretches of time into timeless eternity." 15

According to this African understanding, time rather moves from present (Sasa) to past (Zamani), and not so much from past, to present, to future. Sasa is about that which is of immediate concern for people; it stretches into a relatively short future; it swallows up so-called "future". Past and present overlap and the present is swallowed up in the past; past and present come to rest in the graveyard of time. The present exists to serve the past, which in turn gives purpose to the present. In short: the present does not so much

13 Sunday Fumilola Babalola and Olusegun Ayodeji Alokan, "African Concept of Time, a Socio-Cultural Reality in the Process of Change". Journal of Education and Practice, Vol. 4, no. 7 (2013): 143-147.

14 Babalola, "African Concept of Time", p. 145.

15 Babalola, "African Concept of Time", p. 147. 
influence the future, as it serves the past. The difference with Western time would then be that the so-called Western "future" extends much further than the African "future". ${ }^{16}$

Some critics of Mbiti have stated that he practises a type of "reversed teleology", in which time is conceived backwards. But this critique is indeed only valid if "time" is indeed understood as a linear unfolding of past, present, and future - which could be measured (mathematically) in terms of seconds, minutes, hours, days, etc. Only if one evaluates Mbiti's understanding of time from this linear, temporal-mathematical perspective, one could say that his African concept of time is the "mirror opposite" of the West. ${ }^{17}$ Of course Mbiti knows that Western and even certain Biblical concepts of time mostly operate with a linear perspective, but regarding the latter, he concludes that "though widely accepted as the only scriptural one, [it] is not the only valid one, but that the two-dimensional concept of time is equally valid." 18

This idea of actual time and potential time - Mbiti's so-called twodimensional (or: dyadic) concept of time has however been criticised as not being representative for the whole of Africa. ${ }^{19}$ African understandings of time - as understood by Mbiti, amongst others - has indeed changed with the coming of the Christian missionaries to Africa - the latter exposing African temporality to a more linear take on time. ${ }^{20}$ Especially Mbiti's postulation of African time as being short on future has come under critique. It has for instance been pointed out that in the "house-rules" of the old Oyo Kingdom of the South West Nigeria (1754-1796) there were certain checks and balances built in to prevent the monarch from being despotic or autocratic - clearly an indication that even then, Africans had

16 Parker English, Kalumba, Mbiti, and a Traditional African Concept of Time. Philosophia Africana, Vol. 9, no. 1 (March 2006), 54.

17 Booth, quoting Mbiti, “Time and African beliefs revisited”, p. 84.

18 J. H. Nieder-Heitmann, An Analysis and Evaluation of John S. Mbiti's Theological Evaluation of African Traditional Religions (Unpublished MTh, Stellenbosch, 1981), p. 82 .

19 S. O. Imbo, An Introduction to African Philosophy (Lanham: Rowman \& Littlefield, 1998), p. 61. See in particular also Kwame Gyekye, An Essay on African Philosophical Thought. The Akan Conceptual Scheme (Philadelphia: Temple University Press, 1987), pp. $33 \mathrm{ff}$.

20 Babalola, "African Concept of Time", p. 145. 
a longer, more extended view on the future. ${ }^{21}$ Mbiti himself does contend that the cycle of seasons will "continue forever" 22 - an indication that his own understanding of the "future" is not that short-sighted as many would believe it to be.

Mbiti's concept of time does in fact accept the linear progression of time as one dimension, but also stresses the communal dimension, namely that time is "created" by events within community. For him, African notions of time hinges on the timing of event. Time is tied to events. ${ }^{23}$ In other words, time must be experienced to become real for people, and, only the past and the present have been experienced by anyone. ${ }^{24}$ For Mbiti, time is composed of events, and events must be experienced to be real:

Time has to be experienced in order to make sense or to become real ... Since what is the future has not been experienced, it does not make sense; it cannot, therefore, constitute part of time, and people do not know how to think about it - unless, of course, it is something which falls within the rhythm of natural phenomena. ${ }^{25}$

These events are however of a communal nature and relevance: "Time is not duration as it affects the fate of the individual, but it is the rhythm of the breathing of the social group." 26 Perhaps it could even be postulated that the image of a spiral depicts best what Africans understand as time - a spiral that includes both linear and cyclical dimensions - the latter inclusive of (cyclical) events such as droughts, seasons, even rituals, etc. ${ }^{27}$

In my opinion, African notions of time, as for instance put forward by Mbiti, remind us of the importance of "now". ${ }^{28}$ Could it be said that Western

21 Babalola, “African Concept of Time”, p. 146.

22 Mbiti, African Religions and Philosophy, p. 21.

23 Babalola, “African Concept of Time”, p. 144.

24 English, "Kalumba, Mbiti and a Traditional African Concept of Time", p. 54.

25 Mbiti, African Religions and Philosophy, p. 17.

26 Cf. H. Bosman, "All Past and Present but little Future? African and Old Testament Concepts of Time and History", in M. Getui, K. Holter \& V. Zinkuratire (eds), Interpreting the Old Testament in Africa (New York: Peter Lang, 2001), pp. 103; 104-105.

27 Bosman, "All Past and Present but little Future?", p. 103.

28 This is not to say that "African time" is to be romanticised. My contention is, however, to underline some of the contributions that this understanding of time can make towards 
understandings of temporality either become fixated with the (guilt and/ or glamour of the) past, or endeavour to escape to the (planning and/or developing of the) future? That it could in fact lose out on the promise of the presence? ${ }^{29}$

To put it in even more contentious words: there is, in fact, no such thing as the "past" or the "future". ${ }^{30}$ The past is the past (i.e. no longer there), and the future is the future (i.e. not yet there). The only thing that is "there" is "here", i.e. now. By this, I am obviously not saying that the past never happened, or that - hopefully - the future will never happen. But we do not "have" past or future; we only "have" now.

This comes close to what Saint Augustine - another African! - said concerning time. ${ }^{31}$ According to him, it is in fact not correct to talk about three separated times (past, present, future). He prefers to speak about a present of things that have already happened, a present of things that are happening, and a present of things that must still happen. In his own words:

a more holistic understanding of our temporality.

29 Of course, there are also different understandings of "Western time". Someone like Paul Ricoeur has, for instance, argued that time has cosmological, phenomenological, and narrative dimensions. Phenomenological time is time as we experience it; cosmological time runs according to the calendar and clock, and narrative time acts as a conduit between these two "times". See Paul Ricoeur, Time and Narrative, Volumes 3, trans. Kathleen Blamey and David Pellauer (Chicago and London: University of Chicago Press, 1988), p. 109.

30 "Time" is a human construct - to be shaped as seems necessary. A case in point would be the fact that the $31^{\text {st }}$ of December 2016 was one second longer as it would normally be measured to be. So, we do not only construct something like a "leap year", but also a "leap second"! This decision to add a leap second to 2016 was taken by the Observatory of the American Naval Academy in Washington, after calculating that the atomic watches guarding over the "correct" measurement of time in France indicated that a second was "lost" somewhere - or is it sometime? So, the countdown to 1 January 2017 paused for a second (literally), flashing the number one, or the number zero twice - to "make up for lost time." This is however not the first time that time has been adjusted: The so-called Solar Year is not 365 and a quarter of a day, as previously proposed, but rather 365 days, 5 hours, 48 minutes, and 45 seconds. So, consequently, in our human calculations of time, time was "lost", and the scientists discovered in 1582 that our calendars were 10 days out of step with "real time" - whatever that may be. This meant, inter alia, that (the time of) spring was slowly becoming (the time of) winter in the Southern Hemisphere. The wise people decided to let Thursday, the $4^{\text {th }}$ of October 1582 be followed by Friday, the $15^{\text {th }}$ of October 1582 . So, officially, the time from the $5^{\text {th }}$ of October 1582 until the time of the $14^{\text {th }}$ of October 1582 does not exist! Did it ever?

31 Saint Augustine was the bishop of Hippo Regius (modern-day Annaba, Algeria). 
Perhaps it might be said rightly that there are three times: a time present of things past; a time present of things present; and a time present of things future. For these three do coexist somehow in the soul, for otherwise I could not see them. The time present of things past is memory; the time present of things present is direct experience; the time present of things future is expectation. ${ }^{32}$

Time is all about the connection between events (past, present, future), as experienced in the "now" - but then this "now" should also not be understood in the traditional (mathematical) way as being one point in time in a linear unfolding of times. "Now" takes on a new meaning, at least within African thinking. If we follow Saint Augustine's argument, all that we have of the past are memories, monuments, sites, recordings, etc. - but we can only access them now, in the present. All that we have of the future are things like projections, expectations, hope - but likewise, we can only access them now, in the present. This "access" represents a type of "timetravel" in the mind and imagination, a "time-travel" that however always takes place "now".

As popular as the notion of real, i.e. physical "time-travel" might be travelling to the past or the future - it cannot be done, at least not yet! We are (always) in the now of now. What was in the past that is accessed in the present by means of memory, etc., and what will be in the future that is accessed in the present by means of hope, etc. calls for observation and interpretation in the present. In terms of the topic of this paper, this process of observation and interpretation could also be called: preaching. ${ }^{33}$

\section{Preaching the present}

Of course, the African understanding of time does hold enriching possibilities for our evaluation of the past, as well as our visions of the

32 St. Augustine [1], Book 11, Chapter 20, Heading 26. Quoted from St. Augustine, The Confessions, English version; Bibliothèque de La Pléiade: Paris, France, 1998. [Online] Available: http://www.ourladyswarriors.org/saints/augcon10.htm (Accessed 12 November 2016).

33 "Preaching ... normally focuses on the present moment, on orality and aurality, memory, delivery, bodily enactment, and articulation of meaning in the 'now' before a congregation." Paul Scott Wilson, "Preaching, Performance, and the Life and Death of "Now", in J. Childers \& C. J. Schmit, (eds.), Performance in preaching (engaging worship): Bringing the sermon to life (Grand Rapids, MI: Baker Academic, 2008), p. 37. 
future, but in this paper I limit myself to a discussion of the African notion of the present. In particular: how does this focus on, and appreciation of, the importance of the present, of now, enrich our preaching? A few (perhaps paradoxical) comments on this:

First, the fullness of the present can indeed not be mathematically equated with the duration of a second, or minute, or hour, etc. Now is filled with the past and the future; it is inundated by our memories and our hopes. In preaching, "now", although fleeting, should not be mistaken for occasionalism. "Now" remains linked to the past and the future. The art of preaching consists, inter alia, of understanding this link; of "placing" the present within the coordinates of past and future. "Now" does not come from nowhere. In African thought, at least according to Mbiti, the present (Sasa as actual time) is inseparably linked to the past (Zamani as timeless eternity), as well as the future (as potential time).

It should however be noted that, in African thought, the notion of "now" cannot simply be equated to the (Western) understanding of the "present". "Now" rather indicates the symbolic value of an event. Understood in this way, the "present" is transposed into a type of quality of experience that is determined by sharing and communality. "Now" is a qualitative term that links the so-called caesuras of time (past, present, future) to form a remembrance that gives value to existence, namely the acknowledgement of being human via relationships. For this reason hierarchy is also important, in which the elders call life's experience into remembrance, and in doing so, integrates them. Therefore the elders deserve to be respected. ${ }^{34}$

This recalling of life's experiences takes place by means of song, dance, stories, etc. - often with symbols taken from the immediate natural contexts, e.g. animal life. The stories, etc. then serve to conserve the values and traditions of the group and to transpose them from generation to generation. In this process, "past", "present", and "future" fade away and are transformed into a type of trans-existence; it attains a mythical value of generative, continued existence. In this sense the importance of the spirits of the ancestors could also be understood as guardians over this

34 Cf. the interesting discussion of the role of elders in African society by Matei Markwei, "Life in our Village", in African Writing (eds), by P. Zebala and C. Rossel (London: 1979), pp. 15 f. 
trans-dimension. "Now" is therefore not a fleeting second, but rather the rhythmic recalling and retelling of life within the mythical network of existence; it is rather a trans-temporal, existential quality. ${ }^{35}$

As noted earlier: In Africa, time is tied to events. But that is probably not enough said. Events are also tied to time. Africans time the event; they however also invent (event!) the time. In my opinion, this reciprocity represents a remarkable correlation with so-called modern astrophysical notions of time. According to these notions, time is continuously being affected, moved, shaped, and warped by events in time. If I may borrow a metaphor from nature to try and describe this dynamic reciprocity between event and time: time is like a wave in the ocean. ${ }^{36}$ It has a backside, a force behind its movement - call it the past if you like. It has a crest, forever (!) moving forward, curving, gathering or losing momentum - let us call this movement the present. But the wave is indeed also moving forward, poised to break - somewhere in its future.

There is more than one wave, more than one moment of now, moving from the energies of the past towards the possibilities, the potentialities of a breaking future. This movement I would call "now", being influenced by events, just as the movement of the wave is influenced by objects like the presence of sand banks or rocks, the depth of the ocean, the strength of the wind, or the proximity of the shore. In short: now is movement, not a monument being erected in the centre of the ocean, trying its best to resist the force of the waves, standing fixed and firm against the gale. Preaching is, in my opinion, the art of riding the waves of now; more than constructing a monument that must withstand the movement of these waves. Preachers are surfers of the waves of God's grace of now; not site inspectors of steel constructions that must somehow preserve God's presence with us.

35 On the role of ancestors in African religion, cf. E. B. Idowu, African Traditional Religion: A Definition, (London: Fountain Publications, 1991), pp. $179 \mathrm{f}$.

36 Graciously following a cue given by Paul Scott Wilson, Preaching, Performance, pp.3752. Hans von Baeyer also uses the notion of water to describe the nature of "space-time": it is like an invisible stream that bends and is curved in response to objects, but still carries all things along on its winding path. Hans von Baeyer, "Gravity", in Rainbows, Snowflakes, and Quarks: Physics and the World around Us (New York: McGraw-Hill, 1984), pp. 9-31. 
Second, this emphasis of the present, and the experience of events within the present, should not be equated to a narcissistic take on life, a type of stance that says, or perhaps sings with Freddie Mercury of the British rock group Queen - "I want it all, and I want it now!"37 The "now" of African rhythm does not know this kind of aggressive, temporal command and demand. Now is more than just a (mathematically measured) second, to be filled with as much pleasure as possible.

Speaking again in terms of preaching: now is rather (the experiencing of) an event, filled with the revelatory presence of God. This presence of God is indeed more than just a mathematically defined present; rather a moment of experience, of the event of exposure before God's face, of the experience of truth within the event of an encounter. In this sense, "now" is not a temporal term, at least not primarily, but rather a relational term. In preaching, the present is constituted by this presence of God - an event that calls for hermeneutical observation and interpretation. This presence of God grants the gift, the present of the presence - as actual time.

Actual time could also be called fulfilled time, or in biblical terms: Pleroma. ${ }^{38}$ To experience actual time is to experience the fullness, the Pleroma, of a given time in a given place. Pleroma, in the biblical sense of the word, indicates the fulfilment of God's intent in time and space, particularly in Christ. "In Christ", all things, also cosmological, are unified and brought to its fruition. ${ }^{39}$ The notion of Pleroma has been described in many ways. ${ }^{40}$ For me, Pleroma indicates God's intent being historically revealed within cosmological context as well as eschatologically concealed within signatory form. This means that the fullness of experience of an encounter with God is a reality, i.e., historically real, but as such also has

37 "I Want It All" is a song by British rock band Queen, featured on their 1989 studio album The Miracle.

38 For a discussion of Pleroma, see Johan Cilliers, A Space for Grace. Towards an Aesthetics of Preaching (Stellenbosch: Sun Press, 2016), pp. 44ff.

39 Cf. Ephesians 1:10

40 In the classic works of the Dutch theologian, Arnold van Ruler, we find, for instance, a description of no less than ten characteristics of pleroma (what he calls "vervulling"; fulfilment), namely its historical, concealed, signatory, pluralistic, paradoxical, sacramental and cultural, universal, cosmological, ordinary and irresistible dimensions. A. A. van Ruler, De Vervulling van de Wet. Een Dogmatische Studie over de Verhouding van Openbaring en Existentie (Nijkerk: Callenbach, 1974), pp. 72-79. 
an effect on things cosmological. Time and space, seen cosmologically, are affected by the reciprocal and historical encounters between God and human beings. But these experiences of fullness of encounters are also preliminary; i.e., Pleroma is preliminary, awaiting (further) fulfilment, without diluting the fulfilment of the historical dimension. Therefore, these experiences of Pleroma are often given to us in the form of signs, of fragments and outlines - which could easily be overlooked, and which calls for discernment. In my opinion, preaching contributes towards this discernment of the "now" of Pleroma.

We are "here", in the "now" of this moment - and then we are gone. Indeed, as the Psalmist stated: our days are like grass; like the flowers of the field. ${ }^{41}$ Now here; tomorrow, no more. But what makes this "here" worthwhile, giving weight and gravitas to this fleeting presence? In the light of the African understanding of time, I would say: the Pleroma of encounters with God, but therefore also with my fellow humans, and may I add: with my fellow non-human creatures and creations. Preaching discerns, and celebrates this Pleroma of encounters.

Third, African time also reminds us of potential time, i.e. of the (inevitable) nearness of the future to the present. Again, in traditional theological terms, this could be called eschatology. The latter is indeed not about a distant future, but rather a future that is always imminent, always before the door, which is always ready to be opened, if not already. Or, in the words of Mbiti:

Sisa has the sense of immediacy, nearness and "newness". It is the period of immediate concern for the people since that is "where" or when they exist. To them, what will constitute future should be extremely brief. This is so because any meaningful event in the future must be so immediate and certain that people have almost experienced it (emphasis JC). ${ }^{42}$

41 Cf. Psalm 103:15.

42 Mbiti, African Religions and Philosophy, p. 17. 
It is quite remarkable that Mbiti's thought reveals some sort of "discrepancy" 43 in this regard: he sometimes describes the inevitable future as potential time, but at the same time he also accepts the near future as actual time (see again diagram on page 3 ). ${ }^{44}$ Personally, I would not call this a discrepancy. Would it be too daring to say that this "overlap" of actual time and potential time, of the elusive and the inevitable in fact articulates a type of African eschatology? That this overlap is more about adventus, than about futurum ${ }^{45}$

In preaching, the future is often misunderstood as an experience of time exclusively related to a futurum, i.e. an attitude or mentality that somehow bypasses the present in its eagerness for the future. In the New Testament sense of the word, advent indicates a close connection between the saving presence of Christ who has already come and the future. The hour that is coming, already is now. ${ }^{46}$ Anticipation of the future - hope - is more about adventus (the continuous coming of the present One), than it is about strange, apocalyptical events in the distant future of the "end times". The notion of adventus transcends temporal categories; it is a term carrying a promise that is not qualified historically, but eschatologically.

It is again remarkable to note how the early Christians had a "bifurcated" sense of time and space, as for instance reflected in the Book of Revelation. ${ }^{47}$ The term "bifurcated" indicates that reality (time and space) actually has two dimensions - that what is evident (for instance the powers of the "empire"), but also the deeper, "real" world of God. This bifurcated worldview has often been misunderstood in terms of an absolute separation between present and future - time is then divided into two consecutive stages: the (evil) present and the (distant) future. But, within the bifurcated view "ordinary" and "divine" life coexist at all times and places.

43 According to English, Kalumba, "Mbiti, and a Traditional African Concept of Time", p. 55.

44 English, Kalumba, Mbiti and a Traditional African Concept of Time, p. 54, 55.

45 See Johan Cilliers, “Time out. Perspectives on liturgical temporality”. NGTT 50, no. 1-2 (2009): 26-35.

46 Cf. John 4: 23; 5: 25.

47 See the enlightening work of Wes Howard-Brook and Anthony Gwyther, Unveiling Empire: reading Revelation then and now (Maryknoll, NY: Orbis Books, 1999), pp. 120135. 
This does not mean that these two worlds are condemned to eternal conflict; rather the conviction is that the world of God has already prevailed and continues to prevail over all forms of worldly empire. The "future" is not merely sequential to "now"; rather they are co-present. In presentorientated societies like those in Revelation (and may I add: in Africa) the "future" is always understood as that which is enduring, i.e. already in the process of becoming. In this sense, eschatology is not about "end-time events", but rather about "real events", or in the terminology of Mbiti: it is about potential time overlapping with real time in such a way, that "now" describes a new way of life. It indeed expresses "the sense of immediacy, nearness and newness"; it is about a future that is "so immediate and certain that people have almost experienced it."

Africans have often been accused of wasting time. In fact, they are not wasting time, but rather waiting on time; they are getting ready for time. ${ }^{48}$ This (inevitable) time to come could be the harvest, or the time for hunting, or the time for sowing. These seasons however indicate more than just annual events such as winter or spring; it rather point towards symbolic rhythms of life. It is the time when "now" makes sense; it is a stance of expectation that waits for the (right) now.

In the West, time (the present) is often viewed as a commodity that must be utilized; it becomes useful for pragmatic and technological reasons. "Time is money". Therefore, time must not be "wasted". In Africa, time must be "created". For this you need the observation and interpretation, as well as the experience of events; you need the individual, but you also need the community. And, more often than not, this cycle of seasons will be marked with religious rites and ceremonies - call it liturgy and preaching if you like - to be celebrated by the community.

\section{The Kairos of the karos}

We see such celebrations already in the earliest rock art, such as that at Lonyana rock in KwaZulu-Natal. ${ }^{49}$ This example depicts a kind of healing

48 See Mbiti, African Religions and Philosophy, p. 19.

49 See discussion by Johan Cilliers, Dancing with Deity. Re-imagining the beauty of worship (Wellington: Bible Media, 2012), pp. $130 \mathrm{f}$. 
dance around a sick person wrapped in a blanket made of animal skin (karos).

The openness of the circle is striking, as if reflecting the inviting nature of the dance: people move towards the circle - and possibly out again? Are they out to find more people to join the dance? Do the animals - ancient representatives of the ecology - also want to be part of the circle?

One could ask why the circle plays such an important role in this depiction, as is the case in many other forms of African art. The answer is deceptively simple, and astonishingly profound: A circle does not have a beginning or an end. It cannot be stretched out in a linear pattern of past, present, and future. It rather signifies security within the community; a sense of belonging within the cycles (circles!) of life and death.

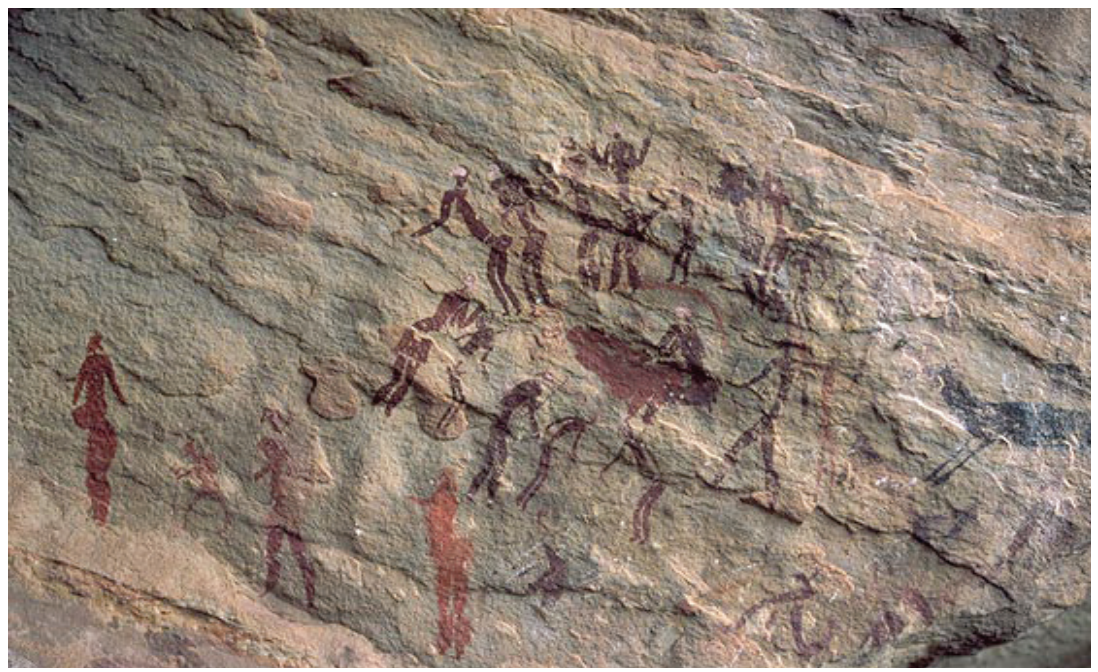

It is significant that the people forming the circle are dancing, i.e. celebrating the seasons of life. Through and within this circle of celebration, the seemingly unstoppable onslaught, the seemingly inevitable progression of time from past, to present, to future, is transcended to form a new experience of the "now" of life. It is not without reason that many scholars are of the opinion that most of these rock-art depictions were intended not only to give expression of everyday events, but to place them within a 
new, transcended framework..$^{50}$ In effect they indicate that all the seasons of everyday life are in fact deeply spiritual, deeply religious, and to be celebrated in such a way that time is no longer viewed as an enemy, but as the space for experiencing the deepest meaning of life..$^{51}$

Rock-art works like these are obviously thousands of years old. Yet, somehow, they offer a diachronic cross-cut of time, of "now". Although painted on rock, millennia ago, they offer an experience of "now", now, i.e. today. They represent a "timeless" take on time; an eventful timing of event, within the celebratory circle of life. It is no wonder that this metaphor of life being danced out in the circle of now found different expressions throughout history - one need only for instance be reminded of the notion of Perichoresis, i.e. of God as Trinity dancing around in a circle. This reciprocal dance is described as an ecstatic sort of dance in which the persons of the Trinity literally "stand outside themselves", while they evoke the life of the godly partners. It is a kind of movement, an interplay of self-offering which makes a reciprocal giving and taking of life possible. It represents the playful and inviting event of healing and homecoming, within the celebratory circle-dance of life. ${ }^{52}$

The particular depiction above indeed illustrates, and celebrates the rhythms of (African) life. Like all good art works, it is open for interpretation. Is it, for instance, about a season of inevitable death, seeing that burials often took place by placing the body in a karos, as a type of natural "coffin"? Or is it about a season of healing, i.e. of potential time? Will the person in the

50 Cf. for instance Tim Forssman and Lee Gutteridge, Bushman Rock Art. An Interpretative Guide (Pinetown: Southbound, South publishers, 2012), pp. $54 \mathrm{ff}$.

51 It is significant that the Shaman and the Rock-art artists was probably often the same person - the Shaman then depicting seemingly everyday scenes, but also from a trancelike, transcended perspective. Cf. for instance the discussion in Bert Woodhouse, Bushman Art of Southern Africa. 40 Significant Bushman Rock-art Sites (Cape Town: Art Publishers, 2003), pp. 1 ff.

52 The term perichoresis was probably used for the first time in a Trinitarian context by Pseudo-Cyril (sixth century), although the term was used earlier by Gregory and Maximus in an Christological sense to express the relation between human and godly in Jesus. Although the word perichoresis does not literally mean "to dance around together" (it is derived from perichoreo, not perichoreuo), various theologians have pointed out the significant wordplay between the two Greek words. In time perichoresis did take on the dimension of the dance, and it does express something of the circular character of the eternal, godly life. See the discussion in Johan Cilliers, Dancing with Deity, 83ff. 
centre die, or rise again? Will the karos become a death shroud, or a shield against the cold of coming winters? Or perhaps we have here a depiction of both, a season of death and birth, within the same circle? ?3 $^{53}$

May Iinterpret this (precolonial) depiction in terms of Mbiti's understanding of African time? Here we have actual time (season of death, before going back into the past) but perhaps also potential time - of healing, of new beginnings. Here we have the rhythms of African existence, of death and life, of life and death, of burial and resurrection - illustrated on a rock that pre-dates time. In short: here we have a celebration of Kairos and karos. Here we have the Kairos of the karos - being danced out within the circle of "now". 54

Punctuality - Punklichkeit - is good, obviously; Kairos - the moment of God's inbreaking in time - is biblical, without a doubt. But punctuality may become commercialised obsessiveness; Kairos may be usurped to serve imperial agendas. The tendency then is to equate certain historical events as biblical, as revelatory, as Kairos. Kairos could then become the Battle of Blood River, viewed from inside the enclave of encircled wagons. ${ }^{55}$ Kairos could read: Gott mit Uns, propagated from Nazi podiums. Yes, Kairos could also be made to fit nicely into many current, South African political claims. ${ }^{56}$

53 Could the idea of birth be strengthened by what some interpret as the figure of the woman with her child in the picture?

54 Theologically speaking, Kairos indicates a fullness of time; a specific time in which God's intentions with this world is fulfilled. The Christ-event signifies the ultimate Kairos, as the Timing of an Event that embodies all of God's revelation. For a discussion of Kairos, see Johan Cilliers, A Space for Grace, $154 \mathrm{ff}$.

55 See Johan Cilliers, "God in Granite? Aesthetic-Theological Perspectives on the Monumentalisation of Religion", Scriptura 114, no. 1 (2015): 1-13.

56 Cf. the "God-with-us" theology of the current ANC Government, from whom we often hear statements like: "God was there at the inception of the ANC - therefore it is the only Party to vote for"; "If you vote for any other Party than the ANC, you will go to hell (sic)"; "If you vote for the ANC, it is your ticket to heaven"; "The ANC will rule until Jesus comes again ..."; and so on. In the precise words of former President Jacob Zuma: "God expects [the ANC] to rule this country because we are the only organisation which was blessed by pastors when it was formed. It is even blessed in Heaven. That is why we will rule until Jesus comes back." And, said at the $105^{\text {th }}$ celebration of the ANC, held in Soweto on the $8^{\text {th }}$ of January, 2017: "As a nation we must never forget this day (of the celebration, JC), because it is like the day on which Jesus was born." In effect, Incarnation becomes Nation. Perhaps some of those that advocate decolonisation sometimes need to be decolonised themselves. 
Therefore I would rather opt to re-qualify the notion of Kairos, placing emphasis on the temporal-relational dimension of communal sharing and caring. When time is experienced as sharing and caring, in particular within the community, and if time is viewed as a gift from God, punctuality becomes infinity, and Kairos takes on the contours of a karos-community. Kairos then is karos; karos is Kairos. This take on time then represents the presence, the Kairos of the caring karos-God, not the imperial God conjured up by iron theologies, or kept intact through the construction of "eternal" monuments. ${ }^{57}$

The depiction above speaks of such a Kairos of a karos-community.

Indeed, here we have time - in the fullest, and most fulfilling, sense of the word.

The West can keep their watch.

\section{Bibliography}

Augustine [1], Book 11, Chapter 20, Heading 26. Quoted from St. Augustine, The Confessions, English version; Bibliothèque de La Pléiade: Paris, France, 1998. [Online] Available: http://www. ourladyswarriors.org/saints/augcon10.htm [Accessed: 12 November 2016].

Babalola, Sunday Fumilola and Alokan, Olusegun Ayodeji, African Concept of Time, a Socio-Cultural Reality in the Process of Change, Journal of Education and Practice, Vol 4, No 7, 2013, 143-147.

Booth, Newell S Jr., "Time and African beliefs revisited”, in Jacob K. Olupona and Sulayman S Nyang (eds.), Religious Plurality in Africa, Essays in Honour of John S. Mbiti, Berlin and New York: Mouton De Gruyter, 1993.

57 For a description of "Iron Theologies", see Johan Cilliers and Charles Campbell, Preaching Fools. The Gospel as a Rhetoric of Folly (Waco, Texas: Baylor University Press, 2012), pp. 63f. 
Bosman, H "All Past and Present but little Future? African and Old Testament Concepts of Time and History", in M Getui, K Holter \& V Zinkuratire (eds), Interpreting the Old Testament in Africa. New York: Peter Lang, 2001. 101-112.

Cilliers, Johan 2012. A Space for Grace. Towards an Aesthetics of Preaching. Stellenbosch: Sun Press.

Cilliers, Johan and Campbell, Charles 2012. Preaching Fools. The Gospel as a Rhetoric of Folly. Waco, Texas: Baylor University Press.

Cilliers, Johan 2012. Dancing with Deity. Re-imagining the beauty of worship. Wellington: Bible Media, 2012.

Cilliers, Johan. "God in Granite? Aesthetic-Theological Perspectives on the Monumentalisation of Religion”, Scriptura 114(1), 2015, 1-13.

Cilliers, Johan. Time out. Perspectives on liturgical temporality. NGTT 50, 2009 (1 \& 2): 26-35.

English, Parker. Kalumba, Mbiti, and a Traditional African Concept of Time. Philosophia Africana, Vol. 9, No 1, March 2006, 54-67.

Forssman, Tim and Gutteridge, Lee 2012. Bushman Rock Art. An Interpretative Guide. Pinetown: Southbound, South Publishers.

Gyekye, Kwame 1987. An Essay on African Philosophical Thought. The Akan Conceptual Scheme. Philadelphia: Temple University Press.

Howard-Brook, Wes and Gwyther, Anthony 1999. Unveiling Empire: reading Revelation then and now. Maryknoll, NY: Orbis Books.

Idowu, EB 1991. African Traditional Religion: A Definition. London: Fountain Publications.

Imbo, SO 1998. An Introduction to African Philosophy. Lanham: Rowman \& Littlefield.

Markwei, Matei 1979. Life in our Village, in African Writing (Eds), by P Zebala and C Rossel. London 1979.

Mbiti, John 1990. “The Concept of Time”, in African Religions and Philosophy. London: Heineman, 1969; second edition, 1990. 
Mbiti, John 1971. Introduction to African Religion. London: Heinemann. Nieder-Heitmann, JH 1981. An Analysis and Evaluation of John S. Mbiti's Theological Evaluation of African Traditional Religions, Unpublished MTh, Stellenbosch.

Ricoeur, Paul 1988. Time and Narrative, Volume 3, trans. Kathleen Blamey and David Pellauer. Chicago and London: University of Chicago Press.

Van Ruler, AA 1974. De Vervulling van de Wet. Een Dogmatische Studie over de Verhouding van Openbaring en Existentie. Nijkerk: Callenbach.

Von Baeyer, Hans 1984. “Gravity”, in Rainbows, Snowflakes, and Quarks: Physics and the World around Us. New York: McGraw-Hill.

Wilson, Paul Scott 2008. "Preaching, Performance, and the Life and Death of 'Now'”, in Childers, J \& Schmit, CJ (Eds.). Performance in preaching (engaging worship): Bringing the sermon to life. Grand Rapids, MI: Baker Academic.

Wiredu, Wasi 1991. “On Defining African Philosophy”, in Tsenay Serequeberhan, ed., African Philosophy: The Essential Readings. New York: Paragon House.

Woodhouse, Bert 2003. Bushman Art of Southern Africa. 40 Significant Bushman Rock-art Sites. Cape Town: Art Publishers. 